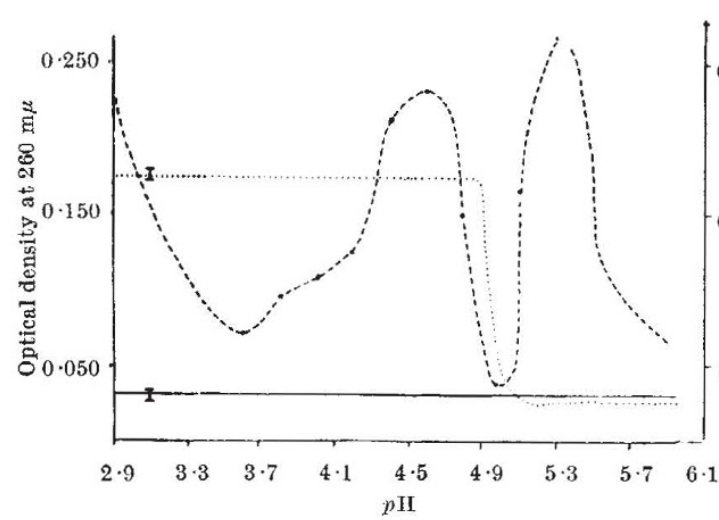

Fig. 1. Amounts of deoxyribonuclcic and ribonucleic acids and bovine albumin remaining unprecipitated by indium at various $p$ II levels and expressed as optical densities of the supcrnatan solutions as described in the text. Ribonucleic acid was dialysed against $0.14 M$ sodium chloride and used immediately afte dialysis. ㄴ.., Deoxyribonucleic acid ; _- - , ribonucleic acid ...., albumi

the ribonucloic acid in solution has been precipitated even at $p \mathbf{H} \mathbf{5} \cdot \mathbf{3}$.

It was found that, by increasing the sodium chloride concentration to $4 M$ (other conditions remaining as described above), deoxyribonucleic acid remained in solution whereas ribonucleic acid under tho samo conditions was procipitatod. Thus, after precipitation of ribonucleic acid at a final concentration of sodium chloride of $4 M$, deoxyribonucleic acid romain, in solution and, in turn, can bo isolatod by dialysis against buffered $0 \cdot 14 M$ sodium chloride followed by addition of indium ehloride to the dialysed solution. The two nucleic acids can be separated from a mixture quantitatively by this procedure.

This investigation, which was supportod in part by a. grant from the U.S. Atomic Energy Committee, will be reported elsewhere in detail, together with data on the isolation of pure nucleic acids from tissues.

William G. Aldordde**

Division of Experimental Radiology and

Department of Anatomy,

University of Rochester School of Medicine and Dentistry,

Rochester, New York.

* Post-sophomore Research Fellow of the National Institutes of Health.

${ }^{1}$ Stern, K. G., and Steinberg, M. A., Biochim. Biophys. Acta, 11, 553 (1953).

${ }^{2}$ Trim, A. R., Biochem. J., 73, 298 (1959).

${ }^{3}$ Kay, E. R. M., Simmons, N. S., and Dounce, A. L., J. Amer. Chem. Soc., 74,1724 (1952).

- Crestficld, A. M., Smith, K. C., and Allen, F. W., J. Biol. Chem., 216,185 (1955).

\section{5-Hydroxytryptamine in Cerebrospinal Fluid}

Although tho 5-hydroxytryptamine content of human cerebrospinal fluid has been reported by Sachs ${ }^{1}$ to increase after various head injurios or cerebral tumours, there appears to bo no other reference in the literature to conditions resulting in an alteration in the content. While studying tuberculous meningitis in children, the opportunity arose for the cerebrospinal fluid to be tested for various amines including 5-hydroxytryptamine.

The cerebrospinal fluid was withdrawn from the patients using conventional methods, taking special care not to contaminate the samples with blood. The fluid was then tested either directly or after acetone extraction on the rat fundus preparation according to the method of $\mathrm{Vane}^{2}$. In 20 cases of tuberculous meningitis, the range of 5-hydroxytryptamino values wes $0 \cdot 2-3 \cdot 0 \mu \mathrm{gm} . / \mathrm{ml}$., whereas in control children it was $0.03-0.1 \mu \mathrm{gm} . / \mathrm{ml}$. The more severe cases always showed high 5-hydroxytryptamine activity. Further, the clinical course of the disease closely followed the 5-hydroxytryptamine content of the cerebrospinal fluid. The significance of these findings is not yet clear.
A. Akcasu
M. AKCASU
S. B. TUMAY

Department of Pharmacology and tho Pediatric Clinic, University of Istanbul.

${ }^{1}$ Sachs, J. Neurosurg., 14, 22 (1957).

'Vane, Brit. J. P'harmacol., 12, 344 (1957).

\section{Viscosity of Concentrated Urea-Lithium Bromide Solutions}

Is the course of studies involving the physicochernical characterization of $a$ proteolytic enzymo from a strsin of $B$. subtilis (NOVO enzyme), viscosity measurements of the protein in concentrated urea and lithium bromide solutions wore undertaken. For those studies, a 1 per cent solution of the protein was employed, and outflow times were measured at $20 \cdot 0^{\circ}$ in a modified Ostwald viscometer.

The results obtained in simple aqueous solution, $8 M$ urea and $7 M$ lithium bromide, are presented in Table 1. The significance of thesse results, in so fer as characterization of the specific protein is concerned, will be discussed olsowhore (Goschwind and Ottoson, to be published). Of interest here are the outflow times found for the solvent, which is both $8 M$ with respect to urea and $7 M$ with respect to lithium bromide. Even in the absence of protein the outflow time for this solution is very great, as is shown in Table 1; tho actual increment in outflow time above that found for water is approximately nine times greater than the sum of the individual inerements for $8 M$ urea and $7 M$ lithium bromide. The outflow time is strikingly dependent upon the concentration of the two solutes, for as shown in tho last line of 'Table 1, dilution of the solution by a factor of less than 8 per cent diminishes the outflow time by more than ono-third. At the higher concentrations of urea and lithium bromide, the addition of protein to 1 per cent further increasos the outflow timo by approximatoly $150 \mathrm{sec}$.

Table 1

\begin{tabular}{|l|c|c|}
\hline \multicolumn{1}{|c|}{ Solvent } & Protcin present & Outfiow time (sec.) \\
\hline Water & - & $67 \cdot 4$ \\
$8 M$ urea & + & $69 \cdot 0$ \\
& + & $99 \cdot 2$ \\
$7 M$ lithium bromide & - & $102 \cdot 5$ \\
& + & $111 \cdot 0$ \\
$8 M$ urea + & - & $722 \cdot 5$ \\
$7 M$ lithium bromide & + & 874 \\
$7 \cdot 4 M$ urea + & - & 469 \\
$6 \cdot 5 M$ lithium bromide & - & \\
\hline
\end{tabular}

